\title{
Wokół problemów prawa autorskiego, czyli spór między Piotrem Świtkowskim a Michałem Gröllem
}

Irena Łossowska 


\section{Irena Łossowska}

\section{Wokół problemów prawa autorskiego, czyli spór między Piotrem Świtkowskim a Michałem Gröllem}

Diotr Świtkowski, redaktor czterech czasopism w XVIII wieku i autor wielu prac, jest jedną z bardziej interesujących osobowości polskiego Oświecenia. Również Michał Gröll, znany księgarz, drukarz i nakładca, należał do ważnych postaci w stolecznym środowisku oświeconych. Przypadek, nieznajomość stosowanych regul, a nawet zla wola którejś ze stron sprawiły, że stali się bohaterami zatargu, który został ujawniony na lamach prasy, a dotyczyl praw do whasności dzieła literackiego.

Wiadomo, że w XVIII wieku, a nawet znacznie późnicj, sprawy te były dalekie od uregulowań formalno-prawnych. Nie obowiązywaly niemal żadne standardy w sprawach wlasności i obrony praw twórcy do dzicła.

Przypomnijmy, że w świadomości wspólczesnej i ogólnym odbiorze każdy utwór ludzkiego działania ma charakter indywidualny, przynależy do określonego twórcy, który ponosi odpowiedzialność za swoją pracę i posiada objęte ochroną prawuą wszelkie atrybuty z tym związane, ze swobodnym dysponowaniem dziełem lącznie.

Relacja dzieło - twórca nie była dawniej tak oczywista, choćby z tego powodı, że funkcjonowała literatura ulotna pozbawiona nadawcy. Wyjątek stanowiła epoka renesansu, nacechowana samoświadomością literacką, żeby przywołać Klemensa Janickiego czy Jana Kochanowskiego. W przekonaniu Jana Trzynadlowskiego nie bez znaczenia dla zjawiska oceny wlasnej twórczości były w XVI wieku wpływ i naśladownictwo dobrych wzorów z kultury antycznej '. Ale nawet w epoce renesansu świadomość wartości osobistych dokonań nie szła w parze z moralnym i prawnym poczuciem własności literackiej². 
Z kolei spuścizna literacka w wieku XVII miała bardzo często charakter rękopiśmienny. Sytuacja historyczno-polityczna, zawieruchy wojenne, często presja cenzury duchownej i świeckiej, a nawet brak ambicji autorskich decydowały, że znakomita większość utworów spoczęla w rękopiśmiennych wariantach odpisowych.

Piśmiennictwo drukowane bogatszego w samowiedzę literacką wieku XVIII ujawniło wiele nazwisk pisarzy, lecz także obdarzyło potomność duzą ilością anonimów i tekstów podpisywanych pseudonimami, szczególnie w czasopismach i zasobach literatury okolicznościowej.

Związki autor — dzieło zaczęly ksztaltować się właśnie w Oświeceniu, choć terminologicznie pojęcie „własność twórcza” była nieokreślona i prawnie niepotwierdzona. Jednakże w osiennmastowiecznej literackiej świadomości społecznej poczucie wlasności funkcjonowato, czego dowodzą blizej niesprecyzowane w praktyce układy międ zy wydawcami-nakładcami i autorami ${ }^{3}$.

Trzynadlowski informuje, że związek między autorem a dziełem w sensie rozpoznawania przez odbiorców autora w jego dziele respektowany był niemal od wieków ${ }^{4}$. Dość przypomnieć pisarkę z XIX wieku, Klementynę z Tańskich I Ioffmanową, która niemal na wszystkich swoich utworach zamiast nazwiska umieszczała na karcie tytułowej opisową formulę „przez autorkę Pamiątki po dobrej matce”.

W świetle dotychczasowych badań przedmiotu okazuje się, że prawne uznanie autorskiej whasności nastąpiło w krajach europejskich i w Stanach Zjednoczonych dopiero w XX wieku. Wcześnicj, na przykład podczas rewolucji francuskiej, wydawano różne dekrety zabezpieczające dzieło, ale nie chronity one osobowości twórcy.

Istotne zmiany wprowadzone zostaly w Kommencji bernenskiej z 1886 roku, ale miały one w ocenie badaczy charakter minimalistyczny i niejednoznaczny. Konmencja modyfikowana przez lata doprowadzila do powstania w poszczególnych krajach ustaw narodowych ${ }^{5}$.

Warto przypomnieć, że polskie prawo autorskie z 1926 roku, jedno z pierwszych w ogóle, zawieralo syntezę nowoczesnej prawnej myśli europejskiej i było oceniane bardzo wysoko".

Przechodząc do postaci tytułowych i uwarunkowań ich ważkiej kulturowo dzialalności, można zacząć od przypomnienia, że Piotr Świtkowski (1744-1793), jeden z najruchliwszych i najpracowitszych redaktorów stolicy, zaliczany byl do fizjokratów ${ }^{7}$. Nie mając odpowied-

\footnotetext{
Ibide'm, s. 15 .

+ Ibidem.

'Dane czerpalam z pracy: A. Wojnicka, Odhroma antorskich dobrosolistych, Lodź 1997, s. 9-54. Autorka wymienia chronologicznic kraje. w których ustawy takic powstaly, między innymi: Polska - 1926, Szwajcaria - 1933. Whochy - 1941. Stany Zjednoczonc Ameryki Pólnocncj - 1976. Hiszpania - 1987. Wielka Brytania -1988 .

${ }^{\circ}$ Ibide'm, s. 9.

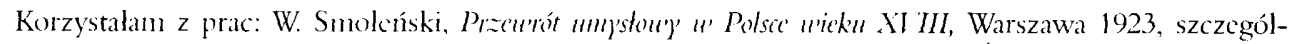
nie s. 320-327; I. I Iomola-Dzikowska, „Paniz̨mik Historyczno-Polityczny" Piotra Śu'itkou'skicgo 1782-1792, Kraków 1960). s. 10-16; a takż wlasuych ustalcú - zob. I. Lossowska. Pior Śu'itkou'ski. [w:] Pisarze polskiego Osiricerenta. red. T. Kosthiewiczowa i Z. Goliniski. t. 2. Warszawa 1994, s. 305-330.
} 
niego przygotowania rolniczego, usiłowat nie tylko teoretycznie, ale i praktycznie (pracując w dzierżawionym pod Warszawą majątku Kalisze) realizować nowoczesne metody agrokultury. W ocenie sytuacji chlopskicj w XVIII wicku zaliczal się go, obok Stanisława Staszica, Hugona Kolłątaja, Józefa Wybickiego i Franciszka Salezego Jezierskiego, do radykalów.

Rodowód społeczny Świtkowskiego jest mniej znany. Był wychowankiem jezuitów. Nowicjat ukończyl w latach 1767-1768 i podjął obowiązki nauczyciela w niższych kolegiach jezuickich. Studia teologiczne rozpoczął w 1772 roku, i mimo kasaty zakonu (1773) ukończyl je w Poznaniu w 1775 roku.

Mówi się, że nie chciał pracować w szkołach Komisji Edukacji Narodowej. W wieku trzydziestu lat zdecydował się na wcześniejszą emeryturę. Początkowo otrzymywał 250 złotych rocznie, później 500, a w końcu - na skutek osobistych próśb do wladz oświatowych — uzyskał pensję 800) zlotych. Dodatkowo ofiarowano mu w charakterze rekompensaty kanonię inflancką.

Wiadomo takze z literatury przedmiotu, ze przebywal w Niemczech, że mecenasowal mu kasztelan krzywiński Antoni Zakrzewski, a takze wlaściciel Rydzyny - August Sułkowski. Podkreśla się również, że późniejsze zaninteresowania Świtkowskiego problematyką ekonomiczną i polityczną były wynikicm jego samodzielnej pracy oraz obserwacji wyniesionych z kraju i zagranicy.

Od startu literackiego w roku 1782 do śmierci w roku 1793, czyli w ciągu jedenastu lat pracy pisarskiej, dokonat bardzo wiele. W 1782 roku notuje siç powstanic „Panniętnika I Iistoryczno-Politycznego". W tym samym roku nakładem Michała Grölla ukazuje się pierwsza książka Świtkowskiego Budou'anic u'icjskic dziedzicom dóbr i posessorom, to

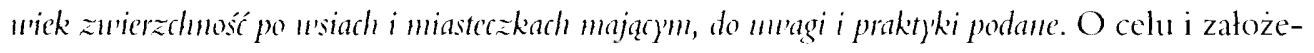
niach programowych edycji informowat na okladce pierwszego numeru swojego .Pamiętnika...". Podkreślał tu potrzebę oświecania obywateli z powodı niedbałego i nieoszczędıego budowania wszelkich budynków gospodarczych.

Projekty w tej mierze docenil król Stanisław August Poniatowski, który w 1783 roku obdarowal go medalem Merentibus. Po raz pierwszy w czasach stanisławowskich zainteresowano się tą problematyką. Na obraz nędznych chat chłopskich zaczęli wskazywać znani publicyści i powieściopisarze. Ci ostatni kreślili wizje wzorowych i higienicznych domów wiejskich w sferze „idyllicznych” tęsknot i marzeń o lepszym chłopskim bytowaniu. Do realistycznych projektów Świtkowskiego wróciło jeszcze Towarzystwo Przyjaciół Nauk, poprzednio o pracy redaktora .Pamiçtnika..." wspominał Grzegorz Piramowicz w Pon'innościad nancz)'icla (1787): jeszcze wcześniej o książce dyskutowano na posiedzeniach Komisji Edukacji Narodowej. Nic dziwnego, że pierwszy jej wydawca, Michał Gröll, zwrócił na Budouranie... baczniejszą uwagę.

Przy omawianiu dorobku Świtkowskiego najwięcej miejsca poświęca się „Pamiętnikowi Iistoryczno-Politycznemu” (1782-1792), który obok "Monitora” (1765-1785) i "Zabaw Przyjemnych i Pożytecznych" (1770-1777) należy do najważniejszych czasopism epoki. W obszernym miesięczniku (80 stron objętości) w formacie ósemki zanieszczal Świtkowski 
wiadomości z kraju i z zagranicy. Traktował o różnorakich sprawach. Z gruntu europejskiego informowat o dokonaniach ekonomicznych i przemysłowych. Omawiając deklaracje i konstytucje z wielı państw, egzemplifikował nimi takic pojęcia jak: oświecenie, równość, tolerancja. Przywolywał autorytety uczonych, polityków i filozofów. Zaspokajal ciekawość czytelnika obszernymi relacjami z odległych krain (Japonia, Chiny, Syria, Egipt). Przypuszcza się, że ten obfity materiał przedrukowywał Świtkowski z zagranicznych gazet, a częściowo dostarczany był czasopismu przez korespondentów.

Wiadomósi polityczne dotyczące Polski najpewniej redagowal sam Świtkowski, o czym świadczą subiektywne komentarze i akcenty propagandowe, w których na użytek szlachty i magnaterii popularyzowat idee wiekı.

O wyjątkowej energii i pracowitości redaktora świadczy fakt, że w trakcie wydawania „Pamiętnika..." podejmował inicjatywy pisarskie. W 1784 roku rozpocząl wydawanie „Magazynu Warszawskiego”, w 1785 roku napisał na życzenie Pawła Ksawerego Brzostowskiego broszurę Ksiązka dla gospodarz)’..., w 1786 podjął się pracy nad czasopismem „Wybór Wiadomości Gospodarskich”. Szczególnie interesujący okazał się „Magazyn...”, w którym zamieszczał Świtkowski dużo materiału literackiego. Skladały się nań wiersze okolicznościowe (Teofili Glinískiej, Wincentego Marewicza), modıe powiastki, relacje z podróży, między innymi słynnego geografa Johanna Reinholda Forstera. Poważniejszą problematykę reprezentowała rozprawa Mosesa Mendelssohna Co to jest Ośu'iecenie. „Magazyn...” miał także swój wkład w powstawanie krytyki literackiej. Świtkowski zamieszczal w piśmie notki o książkach, które miały charakter niewielkich recenzji (na przykład o poemacie Organy' Tomasza Kajetana Węgierskiego lub o powieśsi Michala Dymitra Krajewskiego Wojciech Zdarzyniski).

Mimo różnorodnych ciekawostek czasopismo nie cieszyło się popularnością. Przestało wychodzić w 1785 roku. Również mało interesujący dla współczesnych odbiorców okazał się „Wybór Wiadomości Gospodarskich”. Istniał niespełna rok.

„Pamiętnik...” ceniony współcześnie uczestniczył we wszystkich doniosłych wydarzeniach politycznych okresu stanistawowskiego. Miarą radykalizmu pisma była jego likwidacja przez wladze targowickie we wrześniu 1792 roku. Wypada dopowiedzieć, że czasopismo wywoływało kontrowersje w środowisku stołecznym. Do oponentów „Pamiętnika...” należal głównie Stefan Euskina (właściciel „Gazety Warszawskiej”); jego przyjaciel Karol Wyrwicz w obszernej publikacji Pamięmikon'i Historyczno-Politycznemu pro memoria (cz. 1-3, 1783-1785) zarzucal Świtkowskiemu ignorancję, nieścisłości terminologiczne i błędy stylistyczne.

Krytyka nie we wszystkich przypadkach wydaje się uzasadniona. Zasadność problematykj merytorycznej typu ekonomicznego i politycznego nie budzila wśród oświeconych zastrzeżeń. Trzeba zaś dodać, że potknięcia stylistyczne byly udziałem prawie wszystkich ówczesnych gazet i czasopism. Poza Krasickim i Niemcewiczem w osiemnastowiecznym dziennikarstwie nie uczestniczyły dobre pióra. Przypuszcza się nawet, że przyczyną niedorozwoju polskiego czasopiśmiennictwa w Oświeceniu były nie tylko monopolistyczne praktyk 
przedsiębiorców i brak tradycji, lecz taze po części niedostatki kompetencyjne wśród tych, którzy zajmowali się pisarstwem gazetowym.

O Michale Gröllu (1722-1798) mówi się, że był najwybitniejszym drukarzem i księgarzem polskim okresu Oświecenia. Helena Szwejkowska ${ }^{\star}$ podkreśla, że wprawdzie „silą produkcyjną" nie dorównal oficynie Piotra I) ufoura (drugiego znaczącego wydawcy i drukarza warszawskiego), ale przewyższal go poziomem swego wydawnictwa.

Norymberczyk, uczony mieszczanin, drukarz drezdeński, Gröll na dobre zadomowił się w Polsce od 1759 roku, kiedy zamieszkał w charakterze królewskiego dostawcy ksiązek na zamku. Miał wówczas 37 lat. W pierwszych latach warszawskich zaistnial jako wszechstronny znawca życia codziennego stolicy. W 1762 rokı zalożył bowiem pierwszą gazetę ogloszeniową „Warszawskie Ekstraordynaryjne Tygodniowe Wiadomości” (1762-1763)". Donosił o przedmiotach zaginionych i znalezionych oraz pośredniczyl w najrozmaitszych transakcjach. Pasji i zapewne zapotrzebowaniu społecznemu, a także „intracie” pozostał wierny nawet podczas prowadzenia poważnej działalności księgarsko-drukarskiej.

Witold Piwiński zapewne nie bez przesady pisze:

Gröll używal takiej wziętości w Warszawie, że nazwisko jego obijało się ustawicznie o uszy wszystkich, zacząwszy od tych, którzy królewskie zajmowali pokoje, aż do owych przez los upośledzonych, co spędzali noce letnie na uliach..."

Przyczyny popularności Grölla sugestywnie oddaje w następnym fragmencie:

Zginie piesek na ulicy, poszkodowany whaściciel czyni obwieszczenie i prosi, aby pieska odprowadzono do Grölla w Marywilı..., inny pragnie mieć .madamę" do ıczenia dzieci, używa również pośrednictwa Grölla..., są do odstąpienia prywatne meble, bielizna stołowa, sprzęty kuchenne - w publicznym o tym zawiadomieniu wskazywano Grölla" ${ }^{11}$.

Elita oświeconych poznaje bliżej wydawcę od 1763 roku, kiedy w Marywilu otwiera księgarnię, a przy niej zaklada pierwszą w mieście publiczną czytelnię i wypożyczalnię książek. Także obok lokalizuje salę aukcyjuą i przeprowadza licytację książek. Gröll posiada w księgarni na składzie polskie dzieła z różnych okresów, dużo książek w języku łacińskim i oryginalne edycje zachodnioeuropejskie.

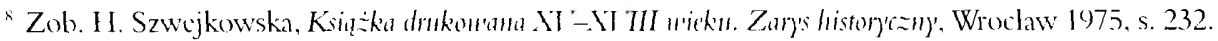

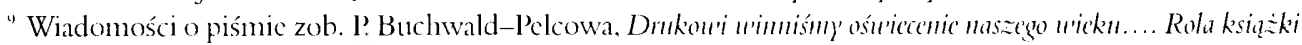
"drodze ku Ośu'eceenu, Warszawa 2003. s. 82.

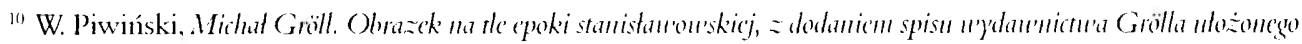
przczZygrmmita Holskiego, Kraków 1898, s. 7-8.

"Ibidcm. s. 10.
} 
Jako wydawca początkowo drukuje zgrabne tomiki in octan'o w oficynach warszawskich i u stynnego Emanuela Breitkopfa w Lipsku. Utrzymuje jednocześnie stale kontakty ze światem wydawniczo-drukarskim w Dreźnie, Lipsku, Amsterdamie, Paryżu i Berlinie.

W 1770) roku po raz pierwszy ukazuje się zbiór Sielanki polskie z różych antoróu zebrane (pod redakcją Józefa Epifaniego Minasowicza, z udzialem Adama Naruszewicza). Gröll w 1778 roku publikuje pomnożony ich zbiór w pięknym, ozdobnym wydaniu, ilustrowanym specjalnie wykonanymi za granicą miedziorytami i drukowanym wlaśnie u wspomnianego Breitkopfa. Ale już w 1778 roku zakłada własną drukarnię (początkowo usytuowaną w handlowym kompleksie Marywilu, później przeniesioną na ulicę Długą, a z czasem na Leszno). Zgodnie z ocenami badaczy, była najnowocześniejszą oficyną w kraju. Wlaściciel doskonale ją wyposażyl. Posiadal różne gatunki czcionck (między innymi kursywę i garmont) i gustowne winiety, stosowal dobry papier z fabryki w Jezionnej pod Warszawą. Mając tak znakomite możliwości, stworzył nowoczesny typ książki.

Drukowal dzieła naukowe, literaturę, czasopisma, kalendarze, książki dla dzieci, podręczniki dla Komisji Edukacji Narodowej, słowniki i publicystykę wszelkiego rodzaju. Właśnie w jego oficynie wydano tekst Konstytucji 3 Maja. Drukował największych pisarzy polskiego Oświecenia, przede wszystkim Ignacego Krasickiego, Adama Naruszewicza, Franciszka Zabłockiego i Franciszka Karpińskiego.

Wspomniany Piwiński, poświęcając sporo miejsca trudom drukarskim Grölla, wydobywa najistotniejszy aspekt jego działalności wydawniczej, a mianowicie wysilek nakładczy. Z wlaściwą sobie emfizą i patosem pisze:

Napisać uczone dzieło, przygotować je w ciagu dłıgich lat mozołu, nie żądać wynagrodzenia, to już wicle poświęcenia, które wyższe umysły składają na rzecz dobra ogólnego... Ale jeszcze do tego wyłożyć na druk z własnego, skromnego woreczka... to już przechodzi miarę zwykłego poświęcenia. Nakładca, który na swoje ryzyko gotowy rękopis nabywa od autora i od wszelkich klopotów, zachodów go uwalnia, świadczy prawdziwą dla literatury usługę ${ }^{\text {I? }}$.

Krasicki - jak twierdzą badacze - nie żądał honorariów za swoje książki. Wprawdzie Gröll na nich zarabial, ale, według słów monografisty, wiele tracił na korsarskich wydaniach i na sprzedaży książek na kredyt, głównie kupowanych przez arystokrację.

Oblicza się, że w okresach największego rozkwitu dzialalności drukarsko-wydawniczej, która miala miejsce podczas Sejmu Czteroletniego, Gröll wydawal szacunkowo od 120 do 20) dzieł (nie licząc woluminów).

Wśród poważnych osiągnięć Grölla wymienia się: wprowadzenie polskiej książki na rynki zagraniczne (targi lipskie); wprowadzenie na state (zainicjowanej przez Wawrzyńca Mitzlera de Kolof) subskrypcji książek; organizowanie publicznych licytacji z jego udziałem jako królew'skim uprzywilejowanym aukcjonariuszem; rozwijanie systemu propagandy książi 
w kraju, zarówno przez wydawanie własnych katalogów, jaki i zakładanie filii ksiçgarskich poza Warszawą, oraz wysyłanie książek na jarmarki, szczególnie na tereny wschodnie.

Badacze podkreślają, żc Gröll, inicjując system nakładczy, zapoczątkował placenie honorariów, co zapewniło drukarzom stałą współpracę z autorami. Nie zawsze układała się ona szczęśliwie (o czym nizej), ale koncepcja umowy o dzieło działała inspirująco na twórców. Dla całej rzeszy nowo powstającej inteligencji, zajmującej się pisarstwem, była zapewne bodźcem motywacyjnym.

Warto dodać, że sama działalność księgarska i drukarska nie dawaly oczekiwanych rezultatów finansowych, skoro niemal wszystkie oficyny, nie wylączając Gröllowskiej, prowadzily różnorodny asortyment handlowy $U$ Grölla na przykład można bylo nabyć nie tylko spowinowacone z książkami mapy, kopersztychy, papier i pergamin, lecz także nasiona i cebulki kwiatowe sprowadzane z I Iolandii, różne mikstury i esencje, porcelanę saską, zegary wiedeńskie, a nawet szczepionkę przeciw ospie, groźnej chorobie w XVIII wieku ${ }^{13}$.

Nicoceniony dziewiętnastwieczny kronikarz Piwiński dodaje, że

...na takich medykamentach oddawanych w komis księgarze zarabiali więcej niżeli na książkach ${ }^{1+}$.

Interesujący nas kontlikt między Gröllem a Świtkowskin nastąpił w 1793 roku. Jego przebieg dowodzi, że relacje autor-drukarz nic były uregulowane prawnic, żc funkcjonowały na zasadzie dobrych obyczajów i indywidualnych zobowiązań między stronami. Być może zaszło w świecie drukarsko-autorskim XVIII wieku więcej podobnych nieporozumień, ale właśnie ten spór znalazł odbicie w ówczesnej prasie, a mianowicie na łamach „Korespondenta Krajowego i Zagranicznego" (1792 - 1796), redagowanego przez ks. Karola Malinowskiego i kompanię. Rzecz dotyczyla wspomnianej już pracy Świtkowskiego Budou'anie uiejskie..., którą po raz pierwszy wydal Gröll z datą 1782, choć formalnie anonsowano dzielo w styczniu 1783 roku. Spore zainteresowanie książką w środowisku oświeconych sklonito Grölla do wznowienia Budow'ania... „Korespondent” ponownie anonsuje dzicło 3 września 1793 roku (nr 71, dodatek, s. 1480):

Budou'anie u'icjskie... z kopersztychami in $8^{\circ}$ (na to dzieło można prenumerować zl 7 gr 15 wedlug osobnego uwiadomienia) -

co oznaczało ogloszenie na książkę subskrypcji. Wydawca, czyli Gröll, nie porozumiał się w tej sprawie $z$ autorem.

O pomyśle powtórnego wydania Budon'ania... dowiedział się Świtkowski z ogłoszenia w „Korespondencie...” i ogłoszeń rozpowszechnionych w stolicy. Poczul się tym głęboko dotknięty, zwlaszcza że sam miał zamiar wznowić edycję i pracował nad poprawą pierwotnego

\footnotetext{
1.3 Szczególowiej na temat szczepionki przeciwko ospic pisze I. Stasicwicz. Z historii szzzépienia ospy', .,Problemy" $196+$ nr 5 .

${ }^{14}$ W. Piwiński, op. cit., s. 25.
} 
tekstu. Zaprotestowal publicznie i swoją wypowiedź ogłosił w „Korespondencie...” już 7 września (nr 72, dodatek, s. 15()3). W słowach nie ukrywających wzburzenia pisal:

Z wielkim moim zdumieniem wyczytałem w przedostatnim „Korespondencie" i rozrzuconych po mieścic afiszach, że dzielo moje Budou'anic u'iejskie ma być ua prenumeratę $u$ p. Grölla przedrukowane. Nigdym się nie spodziewał, aby p. Gröll w sędziwym swym wieku mógł się odważyć na taką podłość. Lepiej jak kto zna on, że książka jaka jest własnością autora. A choć on do książki wspomnianej nabył prawa, jednak prawo to własności wraca się obyczajem naturalnym w calej Europie przyjętym, jak tylko książka wydrukowana, ze wszystkim rozprzedana zostanie ${ }^{15}$.

Jednocześnie ujawnił Świtkowski stare żale związane z otrzymanym honorarium. Także publicznie przypomnial, że Gröll zarobil na jego książce 50() czerwonych złotych $^{16}$, a autorowi wypłacil tylko 15 czerwonych złotych i nie dat mu nawet jednego egzemplarza autorskiego.

Tydzicń później, 14 września Gröll oglosił odpowiedź, także na łamach „Korespondenta..." (nr 74, dodatek, s. 1548). Nie ustosunkowal się do zarzutów autora o bezprawnym wznowieniu książki. W sprawie autorskiego egzemplarza informowal, że w umowie nie wyszczególniono zapisu o obowiązkı przekazania gratisów autorowi. Kwestia honorarium komplikuje się nieco, ponieważ Gröll utrzymywał, powołując się na rachunki podpisane przez Świtkowskiego, że zapłacil autorowi 630 złotych polskich.

Nie odnaleziono dotąd innych śladów działan interwencyjnych Świtkowskiego w tej sprawie. Ale i ta publikacja dowodzi determinacji autora, który, protestując wobec bezprawia wydawcy, usiłował być może odwołać się do jakiegoś arbitra, może chcial zwrócić uwagę opinii publicznej na niewłaściwe zachowanie się zasłużonego drukarza.

Ale trzeba pamiętać, że to był rok 1793. Incydent nie mógł mieć wiçkszego rezonansu. Trwał nowy dramat Rzeczypospolitej na sejmie grodzieńskim. Ratyfikacyjne spory trwały od czerwca do wrześnila tego roku. Znçkane i zbolate społeczeństwo śledzilo jedynie daremne próby oporu przed zaborcami niewiclkiej grupy posłów, zwanej wówczas zelantami.

Zainicjowana polemika Świthowski-Gröll ucichła. Antagoniści nie wypowiadali się więcej publicznie. Jedynie z prasowych anonsów można bylo wyczytać, że strony nie doszły do porozumienia, lecz przeciwnie, zdwoily wysilki przy ,thoczeniu”. Juz 30 listopada 1793 roku oglosił bowiem Świtkowski wiadomośc ${ }^{17}$ o ukazaniu się pierwszej części nowego, poprawionego wydania książki, ale z datą 1794. Postdatację edycji wyjaśnił autor we wstępie, pisząc:

\footnotetext{
15. Okazjonalny opis polemiki Świtkowskicgo z Gröllem zob.: 1. Lossowska-Zaporowska, „Korespondent Warszul'ski" u' lutaih 1792-1796. Warszawa 1969. s. 253-256.

${ }^{\text {in }} 1$. Homola-Dzikowska mylnic informuje o nakladzic książi Św itkowskicgo w 1783 roku i honorarium autora. Bląd wynikal z opuszczenia, istotnego dla obliczén. określenia .czerwony złoty”. Szacunkowo wówczas jeden czerwony zloty odpowiadal 13 zlotym polskim, zob. T. Furtak: Ceny " Gdanisk" u' latach 1701-1815, Lwów 1935. s. 78.

..Korespondent Krajowy i Zagraniczny” 1793 nr 96. dodatck. s. $21+1$.
} 
...różne przyczyny, a nade wszystko przywilej dany na dziesiçć lat przeszlemu właścicielowi i księgarzowi sprawiły, że dopiero teraz mogę wydać powtórnie to dzieło z gruntu prawie odmienione i poprawione... Wszak muszę przyznać: wiele ja sam w nim zauważyłem niedokładności, wiele potem w tej okoliczności znalazłem u postronnych pisarzów nowych wynalazków, sposobów, które zdały mi się być arcyważnymi.

Tytul książki ulegh także modyfikacji. Obecnic brzmial: Budou'nictu'o u'icjskie' pożytkou'i i uyygodzie dziedzicón', zuicrzchnikón' usi naszych i miasteczek pośu'içcone. Niestety, zapowiadane dalsze części poprawionej pracy nie ukazały się. Świtkowski zınarł tego roku 28 gruduia.

Natomiast Gröll donosil prenumeratorom w tym samym dniu o „wyjściu spod prasy” drugiej edycji Budou'ania... w cenie 10 złotych 15 groszy za egzemplarz. Oczywiście, Cröll powielił jedynie starą wersję książki z 1782 roku.

Prawdopodobnie tylko przypadek zrządzil, że edycja Gröllowska ukazala się w dniu śmierci Świtkowskiego. Michat Gröll zmarl w pięć lat później.

Trudno w tej chwili dociekać, która z tych dwóch znaczących osobowości XVIII wieku ponosi większy ciężar odpowiedziahności. Emocje zapewne były po obu stronach, a luki i niedoskonałości w pierwszych monowach autorskich zapewne przyczyniły się do nieporozumień. Sytuację poglębiały ostatnie dramatyczne lata Rzeczypospolitej, ujawniające się nie tylko klęskami politycznymi, ale upadkiem gospodarczym i kłopotami finansowymi. Oficyna Gröllowska z tych właśnie powodów - jak twierdzą badacze - chylila siç ku upadkowi. Drukarz zapewne chciał ją ratować wszelkimi sposobami.

Switkowski byl również w trudnej sytuacji finansowej. W 1792 roku zostal zlikwidowany - jak wspomniano - dochodowy "Pamiętnik I listoryczno-Polityczny”. Redaktor próbował się ratować nowym pismem "Zabawy Obywatelskie” (1792-1793), które byly merytorycznie ubogie i nieciekawe. Pewnie także dla ratowania sytuacji materialnej redaktor mial zamiar wydać w 1794 roku „Pamiętnik Tygodniowy”, co nie doszło do skutku z powodu śmierci.

Powyższy material faktograficzny prowadzi do pewnych wniosków natury bardziej ogólnej. Pamiętamy, że Oświecenie traktuje się w literaturze przedmiotu jako epokę nowoczesną. Wydobywając elementy nowatorstwa, kieruje się uwagę na zjawiska instytucjonalne (czasopisma, teatr, szkolnictwo), podkreśla się osiągnięcia w sferze politycznej (Konstytucja $3 \mathrm{Ma-}$ ja). Także w tych kategoriach dostrzega się działalność drukarską, która szczególnie bujnie rozwinçła się w Wieku Swiatla. Nowoczesne metody rozpowszechniania książki, takie jak reklama, prenumerata, katalogi, a przede wszystkim system nakladczy, zdynamizowały w przekonaniu badaczy - życie literackie i doprowadzily do dużej konsumpcji książki.

Wydaje się, że nowoczesność ujawniła się także w zainicjowanych przez Grölla umowach autorskich. Wprawdzie dalekie były one od pragmatyzmu formalnego, ale niewątpliwie stworzyly bodźce motywacyjne dla rozwoju twórczości, a jednocześnie przyczyniły się do narodzin nowego pojęcia, jakim byla świadomość wlasności intelektualnej. Ugruntowały również znaczenie pracy twórczej, której wyniki przynosiły wymierne korzyści materialne. 
118 Irena Lossowska

Precedensowa polemika Świtkowski - Gröll ukazała nowe instrumenty w batalii o korzystniejsze warunki sporządzania umnów autorskich, jakimi bylo upublicznianie roszczeń autora do nakladcy i wydawcy.

Być może zjawiska, towarzyszące nowemu procesowi walki o własność intelektualną, byłyby kontynuowane, gdyby istniały bardziej sprzyjające okoliczności polityczne. Upadek państwa na dlugie lata przekreślil wysilki w sprawie porządkowania tych spraw. 